\title{
THE RIVER SYSTEMS IN SMALL CATCHMENTS IN THE CONTEXT OF THE HORTON'S AND SCHUMM'S LAWS - IMPLICATION FOR HYDROLOGICAL MODELLING. THE CASE STUDY OF THE POLISH CARPATHIANS
}

\author{
TOMASZ BRYNDAL \\ Institute of Geography, Pedagogical University of Cracow, Poland
}

Manuscript received: 2 April 2014

Revised version: 15 January 2015

\begin{abstract}
BRYNDAL T., 2015. The river systems in small catchments in the context of the Horton's and Schumm's laws - implication for hydrological modelling. The case study of the Polish Carpathians. Quaestiones Geographicae 34(1), Bogucki Wydawnictwo Naukowe, Poznań, pp. 85-98, 3 tables, 7 figs. DOI 10.1515/quageo-2015-0008, ISSN 0137-477X.

ABSTRACT: In ungauged catchments, flood hydrographs are usually simulated/reconstructed by simple rainfall-runoff and routing models. Horton's and Schumm's ratios serve as the input data for many of these models. In this paper, more than 800 Carpathian catchments (up to $35.2 \mathrm{~km}^{2}$ in area) were investigated in context of the "Horton's and Schumm's laws". Results reveal that the "law of stream number" and "law of stream areas" are fulfilled in almost all catchments. The mean that values of the bifurcation ratio $\left(R_{B}\right)$ and the area ratio $\left(R_{A}\right)$ reach 3.8 and 4.8 , respectively, and are thus comparable to values reported in other regions of the world. However, the "law of stream lengths" is not fulfilled in more than half of the catchments, which is not consistent with many theoretical studies reported in the literature. Only $383(48 \%)$ catchments fulfill the "law of stream length", with the mean value of the length ratio $\left(R_{L}\right)=2.3$. There was no relationship found between the geological/geomorphological settings that influence river system development and the spatial distribution of catchments where the "law of stream length" was or was not was fulfilled. A similar conclusion was reached for the spatial distribution of the $R_{B}, R_{L^{\prime}}$ and $R_{A}$ ratios. These results confirmed that the use of Horton's and Schumm's ratios for the evaluation of the influence of geological/geomorphological settings on the river system development is limited. Among the lumped hydrological models, those requiring the $R_{B^{\prime}}, R_{L^{\prime}}$ and $R_{A}$ ratios have been extensively studied over last decades. This study suggests that the application of these models may be limited in small catchment areas; therefore, more attention should be placed on the development of hydrological models where the $\mathrm{R}_{\mathrm{B}^{\prime}}, \mathrm{R}_{\mathrm{L}^{\prime}}$ and $\mathrm{R}_{\mathrm{A}}$ ratios are not necessary.
\end{abstract}

KEY WORDS: Horton, Schumm, river systems, hydrological models, the Carpathians

Address of the author: Tomasz Bryndal, Institute of Geography, Pedagogical University of Cracow, Cracow, Poland; e-mail: tbryndal@up.krakow.pl

\section{Introduction}

The river system is important as it serves to control catchment hydrology and acts as an indicator of geologic and geomorphologic processes (Kirby 1976, Daniel 1981, Cox 1989, Kirchner 1993). The river system develops in a tree-like structure and exhibits tremendous regularity and organization (Bras, Rodrigues-Iturbe 1989).
The river system may be described by many characteristics (e.g. Strahler 1957, Dobija, Dynowska 1975, Bras, Rodrigues-Iturbe 1989, La Barbera, Rosso 1992). Horton was the first to propose quantitative methods to analyze the river systems (Strahler 1957). Horton's "law of stream numbers" (Horton 1945) thus states that $N_{i}$, the number of streams of order $i$, decreases geometrically with stream order: 


$$
N_{i} / N_{i+1} \approx \mathrm{R}_{\mathrm{B}} \text { or } N_{i} \approx \mathrm{R}_{\mathrm{B}}^{\Omega-i}
$$

where $\Omega$ is the order of the network's main stream and $\mathrm{R}_{\mathrm{B}}$ is the "bifurcation ratio".

Horton's "law of stream length" (Horton 1945) holds that $L_{i^{\prime}}$ the mean length of the streams of each order, increases geometrically with stream order:

$$
L_{i} / L_{i-1} \approx \mathrm{R}_{\mathrm{L}} \text { or } L_{i} \approx L_{1} \mathrm{R}_{\mathrm{L}}^{i-1}
$$

where $L_{1}$ is the mean length of the first-order stream and $\mathrm{R}_{\mathrm{L}}$ is termed the "length ratio".

The "law of stream areas," proposed by Schumm (1956), in the spirit of Horton's law, holds that catchment area $A_{\mathrm{i}^{\prime}}$, increases geometrically with stream order:

$$
A_{i} / A_{i-1} \approx \mathrm{R}_{\mathrm{A}} \text { or } A_{i} \approx A_{1} \mathrm{R}_{\mathrm{A}}^{i-1}
$$

where $A_{1}$ is the mean area draining into each first-order tributary and $\mathrm{R}_{\mathrm{A}}$ is the "area ratio".

Horton's approach to river network analysis has been presented and discussed in the literature many times (e.g. Shreve 1966, 1967, 1969, Smart 1967, 1968, 1972, Scheidegger 1968, 1970, Ranalli, Scheidegger 1968, Gutry-Korycka 1987, Bras, Rodrigues-Iturbe 1989, Garcia-Ruiz, Otalora 1992, La Barbera, Rosso 1992, Kirchner 1993), and the $\mathrm{R}_{\mathrm{B}^{\prime}}, \mathrm{R}_{\mathrm{L}}$, and $\mathrm{R}_{\mathrm{A}}$ ratios are usually perceived as measures that quantify the degree of similarity present in a given river system (Tarbon 1996). Some articles contain criticism of Horton's work and propose alternative approaches that describe the river systems more consistently with how they are observed in nature, such as the random topology model (e.g. Shreve 1966, 1967, 1969, Scheidegger 1968, Kirby 1976), or fractal models (e.g. La Barbera, Rosso 1992, Rosso et al. 1991, Tarbaton et al. 1998, Ariza-Villaverde et al. 2013). Kirchner (1993) analyzed the applicability of Horton's ratios when detecting "topologically random/not random" river networks. He showed that statistically, almost all possible networks obey the same laws proposed by Horton and Schumm. He noted that: "If the river systems have distinctive characteristics, Horton's ratios fail to identify them, yielding only the singular imprecise conclusion that natural system networks are some subsets of all possible networks" (Kircher 1993:592). While Horton's ratios have some limitations in geo- morphological analysis (Kirchner 1993, Tarbon 1996), the ratios are commonly used, especially since they have been incorporated into the geomorphologic instantaneous unit hydrograph (GIUH) theory (Rodrigez-Iturbe, Valdes 1979). Since then, the $R_{B^{\prime}}, R_{L^{\prime}}$ and $R_{A}$ ratios have served to provide data for many lumped conceptual hydrological models; for instance, they have been successfully used in ungauged catchments for flood wave simulation/reconstruction (e.g. Rosso 1984, Ziemońska, Żelaziński 1984, Więzik 1987, 2010, Jain et al. 2000, Nasi et al. 2004, Boni et al. 2007). Therefore, determining whether a river network fulfills "Horton's laws" is important for operational hydrology and flood wave modeling. As was emphasized, the relationship on a log plot between $L_{i} N_{i^{\prime}}$ and $A_{i}$ versus stream orders $i$ should be nearly linear (Kirchner 1993). If not, then the $R_{B^{\prime}}, R_{L^{\prime}}$ and $R_{A}$ ratios should not be used for river network characterization in a hydrological modeling process.

The goal of this study is to analyze the river networks of small Carpathian catchments $\left(\mathrm{A}<35.2 \mathrm{~km}^{2}\right)$ in the context of "Horton's and Schumm's laws". The detailed goals are to evaluate the following: 1) whether the river systems fulfill the "law of stream number", the "law of stream length", and the "law of stream area"; if so, 2) what is the growth rate of the river systems and the mean values of the $R_{B^{\prime}}, R_{L^{\prime}}$ and $R_{A}$ ratios?; and 3) what are the characteristics of those river systems where Horton's and Schumm's laws are not fulfilled?

In the Carpathian catchment, which reaches up to $35.2 \mathrm{~km}^{2}$ in area, the region is usually affected by flash flooding (Bryndal 2008, 2014a, b). Given that those catchments are usually ungauged, flood hydrographs are simulated/reconstructed by simple rainfall-runoff and routing models. Horton's and Schumm's ratios serve as the input data for many of those models. From this context, this paper contributes to the regional understanding of a river system's development in flysch mountain areas, specifically in the Polish Carpathian Mountains. It also addresses hydrological and flood risk management issues, especially since many hydrological models that have been developed for runoff simulation require determination of the $R_{B^{\prime}} R_{L^{\prime}}$ and $R_{A}$ ratios (Pristachova 1990, Nowicka, Soczyńska 1991, Ostrowski 1994, Jain et al. 2000, Nasi et al. 2004, Ciupa 2010, Kroczak 2010). 


\section{Materials and methods}

The Hortonian-type of analysis of a river system, based on the type of input data (field measurement, topo-maps, aerial photos, etc.) and methodology used, is a time-consuming process. Nowadays, this analysis is usually based on Digital Terrain Models (DTM) and is supported by many geographic information system (GIS) toolkits (Lindsay 2005, Bohner et al. 2006, Hengl, Reuter 2009, Jasiewicz, Metz 2011).

In this study, the geodatabase of the Polish Carpathians was developed and analyzed by the ARC-GIG 9.3 software with the AcrHydro toolkit (Maidment 2002). The geodatabase consisted of a DTM with a resolution of $20 \times 20 \mathrm{~m}$, interpolated from the point vector data of $1: 10,000$. The river network was imported from the vector map (1:50,000 in scale) and incised into the DTM. In this way, the detailed river network that was presented on the 1:50,000 vector type layer was included in the analysis. This layer served as the input data in the ArcHydro toolkit. The stream network was generated by means of the D8 algorithm (Maidment 2002), classified according to Strahler's ordering scheme (Strahler 1957), and the $i$-order sub-catchments were delineated.

Many GIS toolkits (Lindsay 2005, Bohner et al. 2006, Hengl, Reuter 2009, Jasiewicz, Metz 2011) support the Hortonian-type analysis by using stream ordering classification, segmentation, river sub-catchment delineation, and so on. Some GIS toolkits calculate the $R_{B^{\prime}}, R_{L^{\prime}}$ and $R_{A}$ ratios directly, usually basing on the ordinary least-squares regression. This approach is sometimes criticized because regression assumptions are usually violated (Furey, Troutman 2008). Moreover, points corresponding to a short main stream, and which would thus exert undue leverage, are omitted from $\mathrm{R}_{\mathrm{L}}$ regression, as per typical practice (Kirchner 1993). It is this author's opinion that the "classical approach", supported by log plot analysis, guarantees that Horton's and Schumm's laws of a river system may be evaluated more precisely. As was emphasized, the relationship on a log plot between $L_{i^{\prime}} N_{i^{\prime}}$ and $A_{i}$ versus stream order should be nearly linear (Kirchner 1993), otherwise the $R_{B^{\prime}} R_{L^{\prime}}$ and $R_{A}$ ratios should not be used as input data to characterize a river system in hydrological models. Sometimes, this assumption is not strictly obeyed (Pristachova 1988). The "classical approach" allows one to evaluate whether river systems fulfill Horton's and Schumm's laws and to characterize those river systems where Horton's and Schumm's laws were not fulfilled.

The descriptive statistics provided the opportunity to assess the growth rate of the Carpathian river system, as well as to compare the Carpathian river system with other river systems in other regions of the world. The Carpathians comprise a region where geology, lithology, and relief change cross. The spatial distribution of these catchments enables one to relate the $R_{B^{\prime}} R_{L^{\prime}}$ and $R_{A}$ ratios to geological and geomorphological factors that influence a river system's development.

The river systems of catchments smaller than $35.2 \mathrm{~km}^{2}$ were delineated on the basis of DTM. Taking into account the principles of the Hortonian-type analysis (e.g. Scheidegger 1968), only the catchments with the highest order stream $\Omega \geq 3$ were considered in the analysis.

\section{The study area}

Most of the study area belongs to the Polish Outer Carpathians which are mostly built of flysch rocks folded in Miocene (Oszczypko 1995). The bedrocks are covered by $0.1-2.0 \mathrm{~m}$ thick mantle. Loess-like deposits cover the northern part of the region. Fluvial deposits fill the bottom parts of the main Carpathian's rivers and intra-mountain basins. The flysch Carpathians consist of medium-high mountains (Beskidy), foothills and intra-mountain basins (Fig. 6). The Carpathian Foothills have low relief (100-200 m) which consists of round ridges with gentle slopes $\left(10-20^{\circ}\right)$ and valleys with wide bottoms (100-300 $\mathrm{m})$. The elevation ranges from 500 to $600 \mathrm{~m}$ a.s.l. Well-developed Cambisols and Luvisols form a soil cover, thus it is an agriculture region. Forests cover steeper parts of the hillslopes and small valleys which incise the hillslopes. The Carpathian's Foothills neighbor the medium-high mountain region called the Beskidy. This region has steep slopes $\left(20-50^{\circ}\right)$, the topographic relief ranges from 300 to $800 \mathrm{~m}$ and elevation exceeds $1000 \mathrm{~m}$ a.s.l.. The Acid Cambisols, Lithosols and Rancers form a soil cover. This region is more forested than the foothills. Forests cover upper and steeper parts of the hillslopes whereas arable lands occupy lower and gentler parts. 
The Tatra Mts. are located in the southern part of the study area. The bedrocks consist of the granite rocks (mainly the Eastern Tatra Mts.) and limestones, dolomites (mainly the Western Tatra Mts.). The relief is characterized by steep slopes and the topographic relief exceeds $800 \mathrm{~m}$. The Lithosols, Rankers, Rendzinas, Podzols form a soil cover. This region is covered by spruce forests. The study area has the moderate climate conditions. In the Carpathian Mts. average annual temperature ranges from $7^{\circ} \mathrm{C}$ on the foothills to $0^{\circ} \mathrm{C}$ in the highest parts of the Tatra Mts. Average annual precipitation ranges from $700 \mathrm{~mm}$ to 1600 mm (Obrębska-Starklowa et al. 1995).

\section{Results}

There were 1,031 catchments smaller than 35.2 $\mathrm{km}^{2}$ in area that were delineated on the basis of DTM (Fig. 1). There were a total of 499 (48\%) firstand second-order catchments, and they were excluded from the analysis; these catchments were usually smaller than $3 \mathrm{~km}^{2}$. There were $802(52 \%)$ catchments with the maximum stream order $\Omega \geq$ 3 (Fig. 1). The third-order catchments dominated
$(63 \%)$ in this group; more than $80 \%$ of these catchments were larger than $3 \mathrm{~km}^{2}$ and smaller than 18 $\mathrm{km}^{2}$. The fourth-order catchments accounted for $37 \%$. In this group, $80 \%$ of catchments were larger than $11.9 \mathrm{~km}^{2}$ and smaller than $34 \mathrm{~km}^{2}$. There were only 21 (3\%) fifth-order catchments (3\%); they were larger than $24 \mathrm{~km}^{2}$.

\section{The bifurcation ratio $\left(R_{B}\right)$}

The "law of stream number" was fulfilled in 801 catchments. The average value of the bifurcation ratio $\left(R_{B}\right)$ amounted 3.8 and the diversity measures reached a standard deviation (Std. Dev.) of 0.93 and had coefficient of variation (Coef.Var.) of $24 \%$ (Fig. 2A). Ninety percent of the catchments had an $R_{B}$ ratio lower than 4.8 (Fig. 2A). Significantly higher values of the $R_{B}$ ratio (outliers and extreme observations on the box plot) were observed in 20 catchments (Fig. 2A). The highest $R_{B}$ ratio reached 9 .

As the empirical results indicate, the $R_{B}$ for natural catchments normally ranges from 3 to 5 (Smart 1967, 1972, Bras, Rodriguez-Iturbe 1989). An $R_{B}$ ratio ranging from 3 to 4.5 was found to be typical for the large Carpathian catchments (Ba-

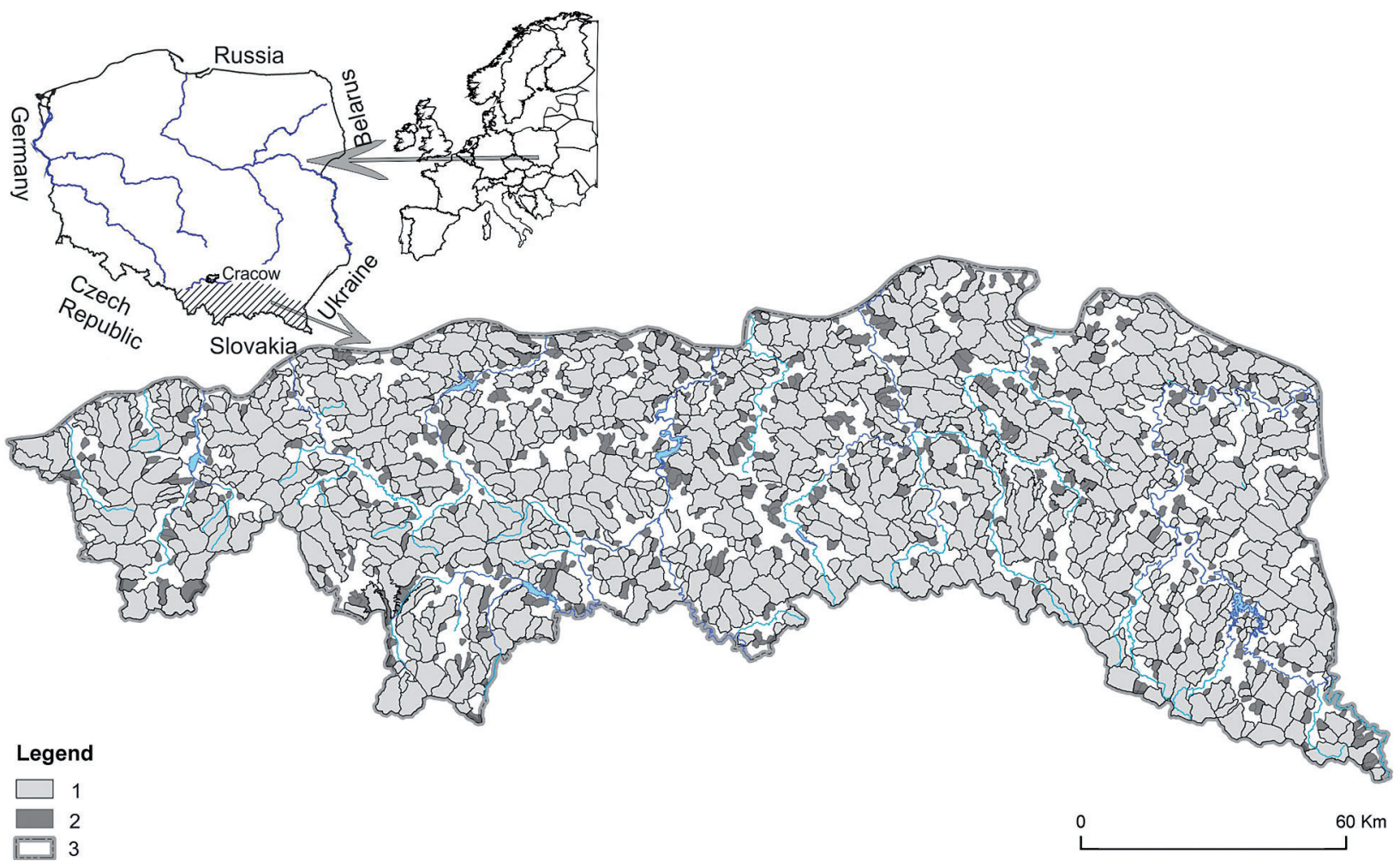

Fig. 1. Spatial distribution of the investigated catchments. 1 - catchments with the highest stream order $\Omega \geq 3,2$ - catchments with the highest stream order $\Omega \leq 2,3$ - the study area 
jkiewicz-Grabowska 1987); similar values were obtained in this study for the small catchment areas.

The river systems differed in terms of the rate of bifurcation (Fig. 2B). Average values of the $N_{1}$ $N_{2}(4.0), N_{2} / N_{3}(3.8), N_{3} / N_{4}(2.9)$, and $N_{4} / N_{5}(2.2)$ ratios revealed comparable rates of river system development up to the third-order streams (Fig. 2B). Similar conclusions were reached by Morisawa (1962) in the catchments of the Appalachian Plateau. The second-order stream was usually created by 2-6 first-order steams. A similar relationship was observed between the second-order and third-order streams. Similar rates of the bifurcation ratio were reported by Strahler (1957) for small catchments in southern Indiana.

The histograms presenting the rate of bifurcation were right-skewed $-1.5<\mathrm{Sk}<1.9$ (Fig. 2B); similar distributions were reported in the literature (e.g. Bajkiewicz-Grabowska 1987). The bifurcation ratio (mean) decreased as the highest stream order $(\Omega)$ increased (Table 1$)$.
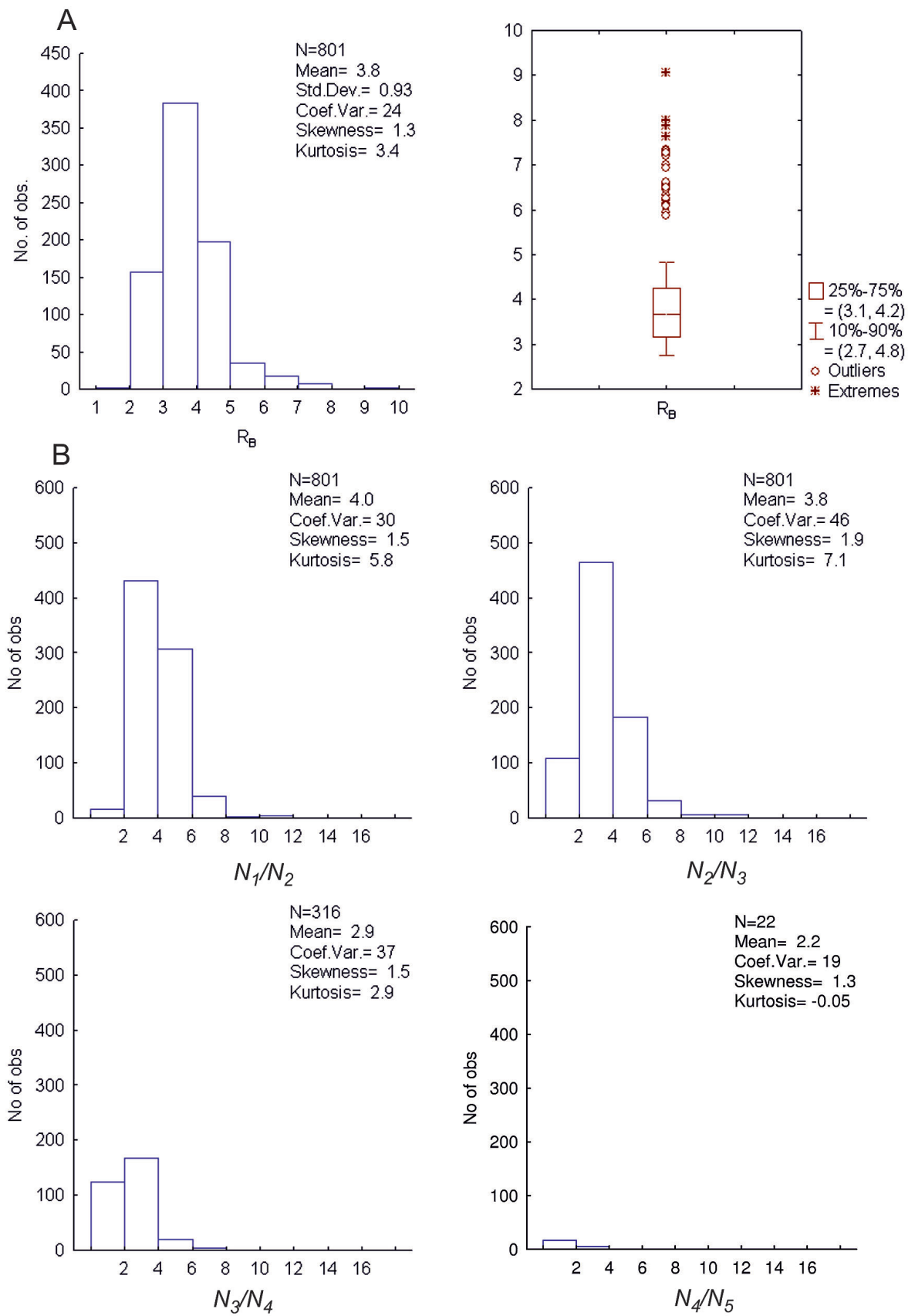

Fig. 2. The bifurcation ratio (RB) in the investigated catchments - A, the growth rate of the bifurcation ratio - B. N - number of catchments, Coef.Var. - coefficient of variation 
Table 1. Mean ratios of the stream number $\left(N_{i}\right)$ in catchments where "the law of stream number" was fulfilled

\begin{tabular}{|c|c|c|c|c|c|c|}
\hline$\Omega$ & $\begin{array}{c}\text { Number of } \\
\text { catchments }\end{array}$ & $N_{1} / N_{2}$ & $N_{2} / N_{3}$ & $N_{3} / N_{4}$ & $N_{4} / N_{5}$ & Mean \\
\hline 3 & 485 & 4.0 & 3.7 & - & - & 3.9 \\
\hline 4 & 294 & 4.1 & 4.0 & 3.0 & - & 3.7 \\
\hline 5 & 22 & 4.4 & 3.4 & 2.9 & 2.2 & 3.2 \\
\hline
\end{tabular}

$\Omega$ - the highest stream order within the catchment.

\section{The length ratio $\left(R_{L}\right)$}

The "law of stream length" was fulfilled in $383(48 \%)$ catchments. The average length ratio $\left(R_{L}\right)$ reached 2.3 (Fig. 3A) and the diversity
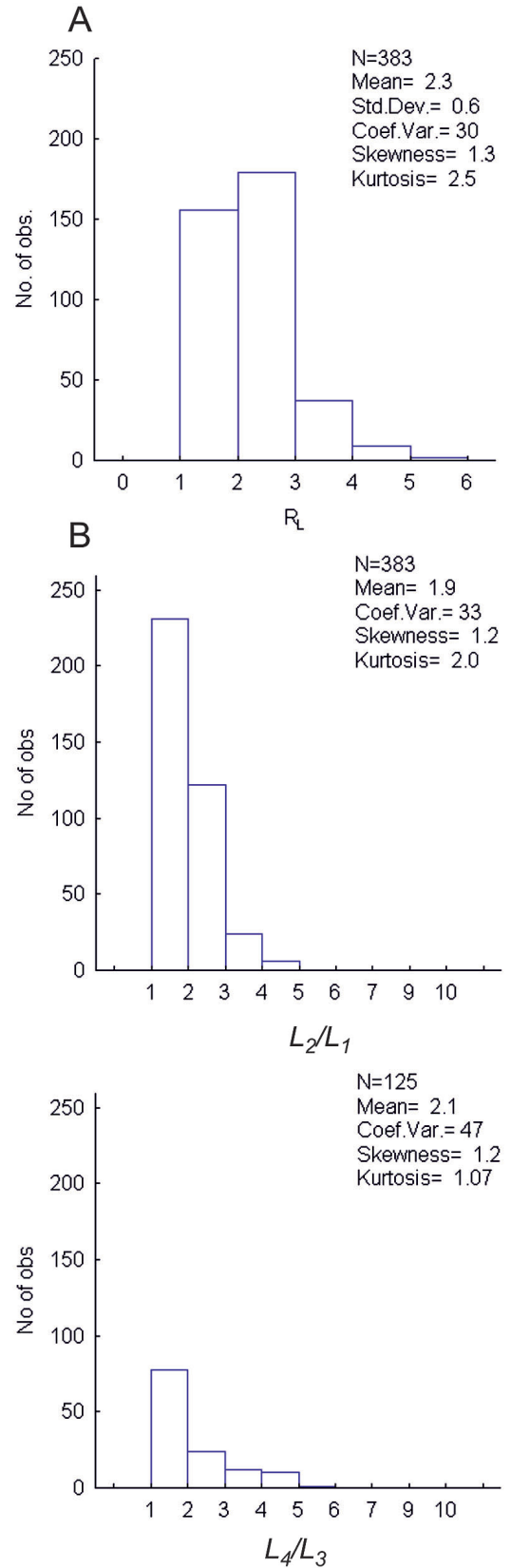

measures (Std.Dev. $=0.6$, Coef.Var. $=30 \%$ ) were slightly higher compared to the $R_{B}$ ratio (Coef. Var. $=24 \%$ ). Eighty percent of catchments had an $R_{L}$ ratio higher than 1.5 and lower than 3.2 (Fig. $3 A$ ). Higher values of the $R_{L}$ ratio (outliers and
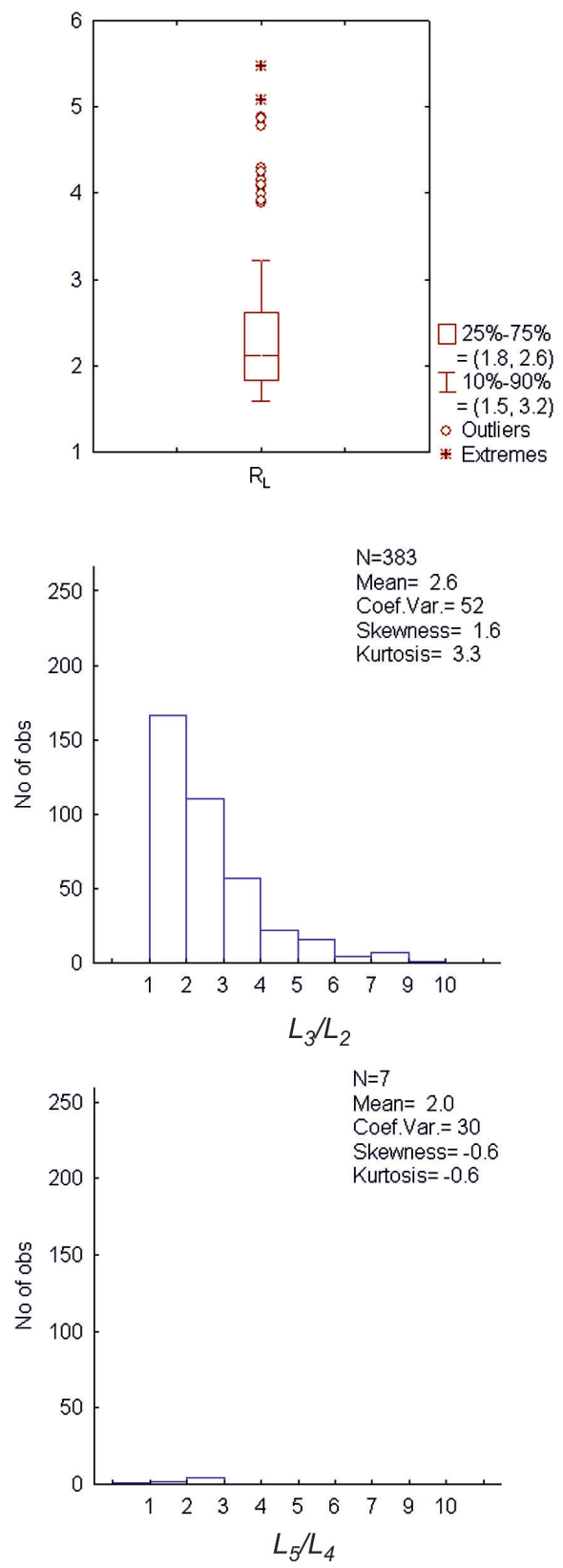

Fig. 3. The length ratio $\left(\mathrm{R}_{\mathrm{L}}\right)$ in the investigated catchments $-\mathrm{A}$, the growth rate of the length ratio - B. Labeled like Fig. 2 
extreme observations on the box plot) were recorded in 15 catchments (Fig. 3A). The highest value of $R_{L}$ reached 5.5.

For natural catchments, the $R_{L}$ ratio usually ranges from 1.5 to 3.5 , with the mean equal to 2.0 (Smart 1968, 1972, Bras, Rodriguez-Iturbe 1989). An $R_{L}$ ratio ranging from 1.5 to 3.5 was found to be typical for the large Carpathian catchments (Bajkiewicz-Grabowska 1987). The $\mathrm{R}_{\mathrm{L}}$ ratios obtained in this study are comparable to those reported for other regions in the world.

The average values of $L_{2} / L_{1}, L_{3} / L_{2,} L_{4} / L_{3^{\prime}}$ and $L_{5} / L_{4}$ increased and reached 1.9, 2.6, 2.1, and 2.9, respectively. The mean length of the first-order stream reached $0.5 \mathrm{~km}$ (Coef.Var. $=30 \%$ ) and this value increased as the stream order increased (Table 2). The rates of the length ratio are comparable to those found in other regions of the world (Morisawa 1962).

More than $50 \%$ of the catchments did not fulfill the "law of stream length", even though the "law of stream number" was obeyed. This fact was also emphasized by Bajkiewicz-Grabowska (1987) for large Carpathian catchments. The river systems where the "law of stream length" was not fulfilled usually developed in accordance with one of three models (Fig. 4).

Model I. The river system developed in accordance with the "law of stream length" up to $\Omega-1$ stream order. The average length of the highest stream order is lower than the average length of the $\Omega-1$ stream order segment (Fig. 4A, Model I). A typical catchment where a river system is developed according to this model is presented in Fig. 4B-Model I. The river system is characterized by a great degree of asymmetry, and the second-order streams are longer than the third-order steams.

Model II. The average values of the $i$-order streams increase, but their lengths differ considerably (Fig. 4A, Model II). The catchment presented in Fig. 4B-Model II represents a typical

Table 2. Average length of the $i$ order stream

\begin{tabular}{|c|c|c|c|}
\hline $\begin{array}{c}\text { Steram } \\
\text { order } i\end{array}$ & $\begin{array}{c}\text { Number } \\
\text { of catchments }\end{array}$ & Mean km & Coef.Var. \% \\
\hline 1 & 383 & 0.5 & 30 \\
\hline 2 & 383 & 0.9 & 39 \\
\hline 3 & 383 & 2.4 & 61 \\
\hline 4 & 125 & 3.5 & 44 \\
\hline 5 & 7 & 3.2 & 32 \\
\hline
\end{tabular}

example of this model. The river system in this catchment is usually characterized by a dendritic-type pattern.

Model III. The average length of the second-order streams is lower than the average length of the first-order streams (Fig. 4A, Model III). A typical catchment where the river system developed according to this model is presented in Fig. 4B-Model III. The river system of this catchment is usually characterized by a trellis-type pattern (Fig. 4B, Model III).

These three models describe $70 \%$ of the river networks within the catchments where the "law of stream length" is not fulfilled.

\section{The area ratio $\left(R_{\mathrm{A}}\right)$}

The "law of stream areas" was fulfilled in 797 catchments; four catchments had not fulfilled this law. The average value of the area ratio $\left(R_{A}\right)$ reached 4.8 (Fig. 5A). The standard deviation (1.3) and the coefficient of variation $(26 \%)$ were similar to those of the $R_{B}$ ratio (Fig. 2A). Ninety percent of the catchments had an area ratio higher than 3.4 and lower than 6.4 (Fig. 5A). Significantly higher values (outliers and extreme observations on the box plot) were recorded in 23 catchments (Fig. 5A). The highest $R_{A}$ value reached 11 .

For natural catchments, the $R_{A}$ ratio usually ranges from 3 to 6 (Smart 1972, Bras, Rodriguez-Iturbe 1989). Similar values were recorded in the investigated catchments.

The average values of the $A_{2} / A_{1}(5.6), A_{3} / A_{2}$ (4.6), $A_{4} / A_{3}$ (3.2), and $A_{5} / A_{4}$ (2.3) ratios revealed that the rates of river system development were comparable up to third-order stream (Fig. 5B). Similar conclusions were reached by Morisawa (1962) in the catchments of the Appalachian Plateau. The sub-catchment drained by the second-order streams is usually 4-6 times larger than that of the sub-catchment drained by the first-order streams. A similar relationship was observed between the second- and third-order streams. The histograms of the area ratio in the small Carpathian catchments were strongly skewed to the right (Fig. 3B), which is comparable to distributions reported in the literature (e.g. Strahler 1957, Shreve 1969). The mean area of the sub-catchments drained by the first-order stream reached $0.3 \mathrm{~km}^{2}$; however, the rate of growth 

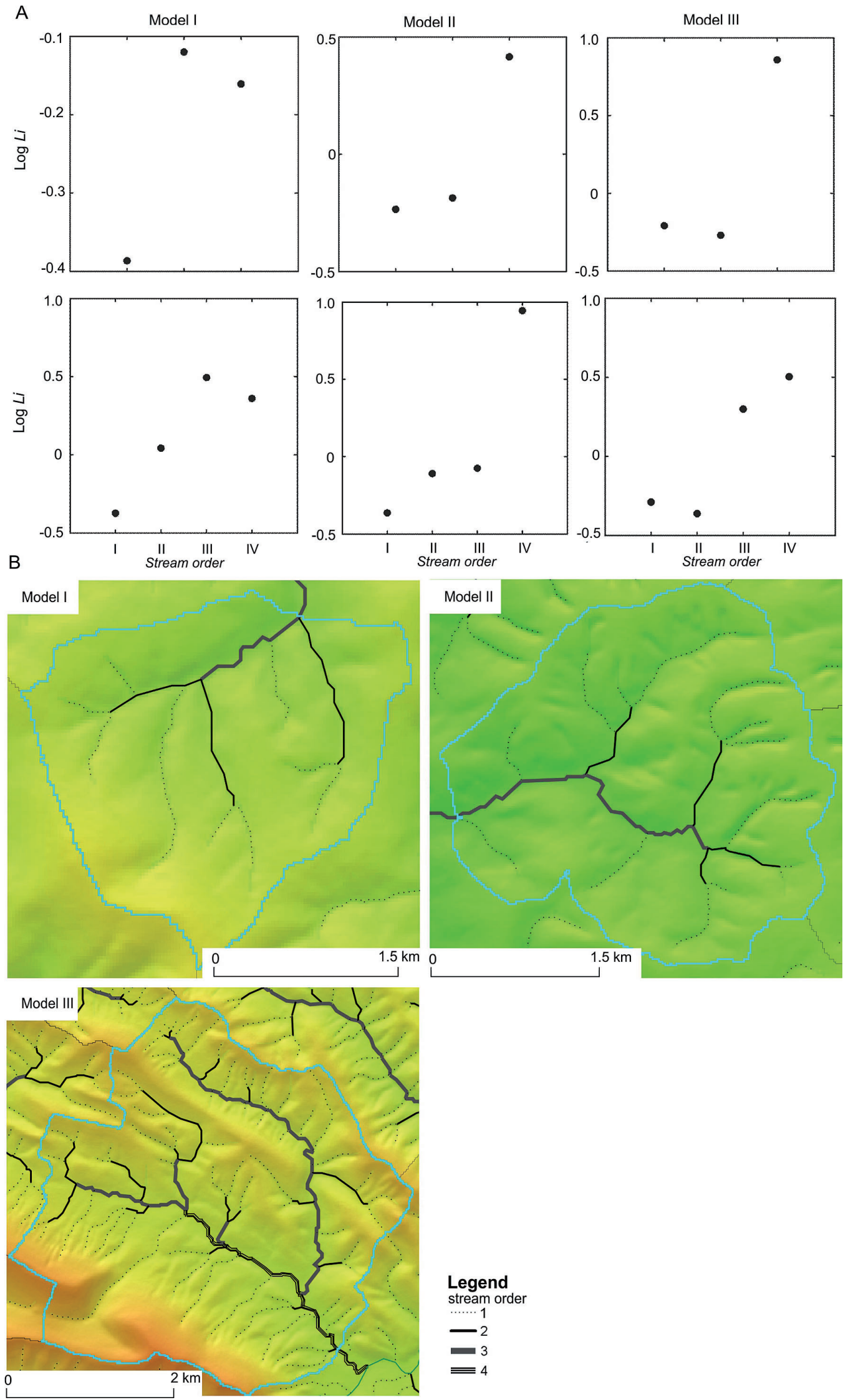

Fig. 4. The models of a river system development in the catchments where the "law of stream length" was not fulfilled - A, Example catchments - B 
slightly differed in subsequent segments (Table $3)$.

\section{Linkage between the $R_{B^{\prime}}, R_{L^{\prime}}$ and $R_{A}$ ratios and the geographical sub-regions of the Carpathians}

Geological settings and relief strongly affect river system development (Shreve 1967, 1968, Daniel 1981, Bajkiewicz-Grabowska 1987, Cox 1989). In the Carpathian Mountains, the geographical sub-regions differ in terms of their geological
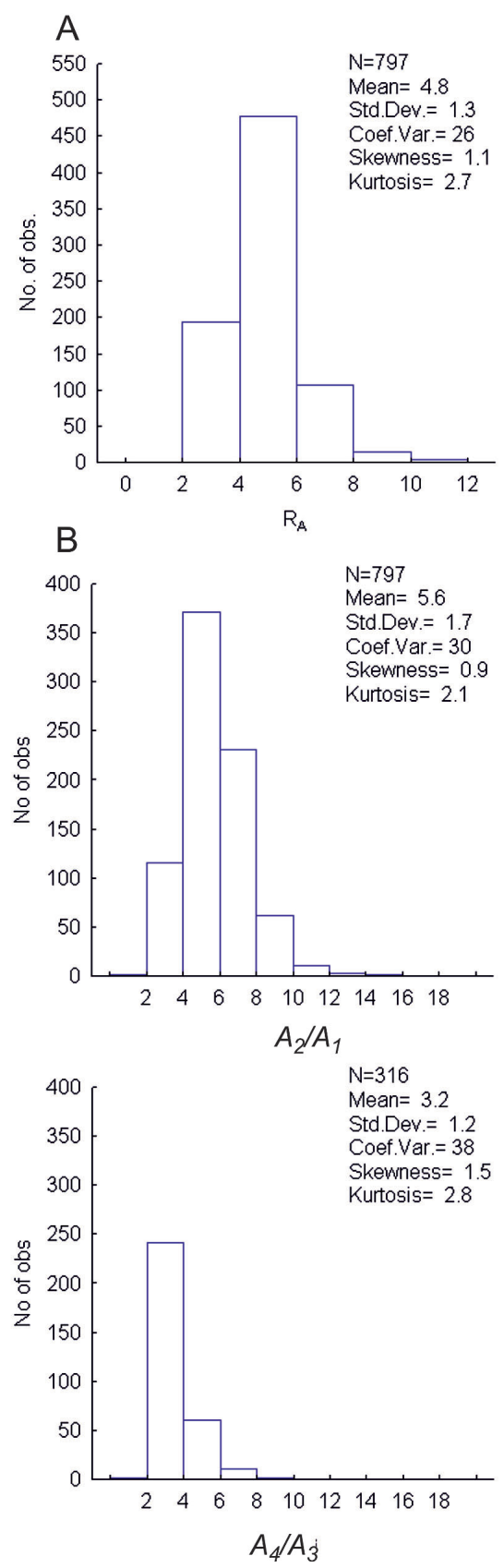

Table 3. Average sub-catchment area of the $i$ order stream

\begin{tabular}{|c|c|c|c|}
\hline $\begin{array}{c}\text { Stream } \\
\text { order } i\end{array}$ & $\begin{array}{c}\text { Number of } \\
\text { catchments }\end{array}$ & Mean & Coef. Var. \\
\hline 1 & 797 & 0.3 & 41.6 \\
\hline 2 & 797 & 1.8 & 52.2 \\
\hline 3 & 797 & 8.0 & 60.0 \\
\hline 4 & 316 & 23.0 & 37.7 \\
\hline 5 & 22 & 31.4 & 13.8 \\
\hline
\end{tabular}

and relief conditions (see the study area). The spatial distribution of the catchments where Horton's and Schumm's laws were fulfilled (Fig. 6) were re-
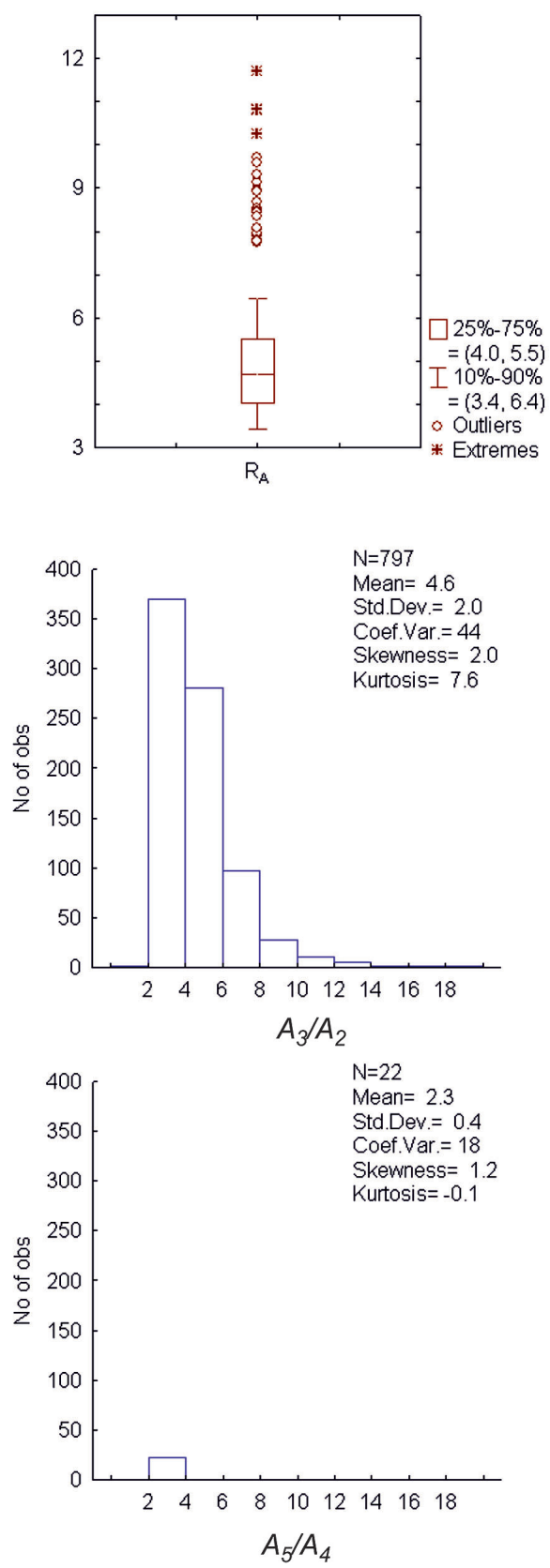

Fig. 5. The area ratio $\left(R_{A}\right)$ in the investigated catchments $-A$, the growth rate of the area ratio - B. Labeled like Fig. 2 
lated to the geographical sub-regions. It is worth noting that the catchments were distributed more or less uniformly in the geographical sub-regions. A slightly higher concentration of catchments was observed on the Carpathian Foothills, where the bedrocks consist of thick layers of loess-like deposits and less-resistant flysch outcrops of Silesian Napple and Skole Napple (Oszczypko 1995). Slightly different conditions occur in other parts of the Carpathians, where more resistant bedrock strongly influences river system development. However, there is no simple relationship between regional changes in geological settings, relief conditions, and the spatial distribution of catchments where Horton's and Schumm's laws were fulfilled. These catchments were identified in almost every region of the Carpathians.

There are no significant regional differences in the values of the $\mathrm{R}_{\mathrm{B}^{\prime}} \mathrm{R}_{\mathrm{L}^{\prime}}$ and $\mathrm{R}_{\mathrm{A}}$ ratios (Fig. 7).
Most of the catchments had an $\mathrm{R}_{\mathrm{B}}$ ratio between 3 and 4 . These catchments were equally distributed on the Carpathian Foothills, in the Beskidy, and in the Tatra Mountains. The same conclusion could be drawn for the catchments where the $R_{B}$ ratios ranged between 4 and 5 (Fig. 7). Slightly higher values of the $R_{B}$ ratio were observed in the western part of the study area - Beskid Mały, the Babia Góra Ridge, Działy Orawskie, Beskid Orawsko-Podhalański, and Gorce (Fig. 7). A similar relationship was observed for the length ratio and the area ratio (Fig. 7). Catchments where the $R_{L}$ ratio was enclosed within classes 1-2 and 2-3 dominated. Slightly higher values of the $R_{L}$ ratio were observed in the western part of the study area. Several catchments had an $R_{L}$ ratio greater than 3 . These catchments occurred in almost every region of the Carpathians. Most of the catchment areas had $\mathrm{R}_{\mathrm{A}}$ ratios between $4-5$ and
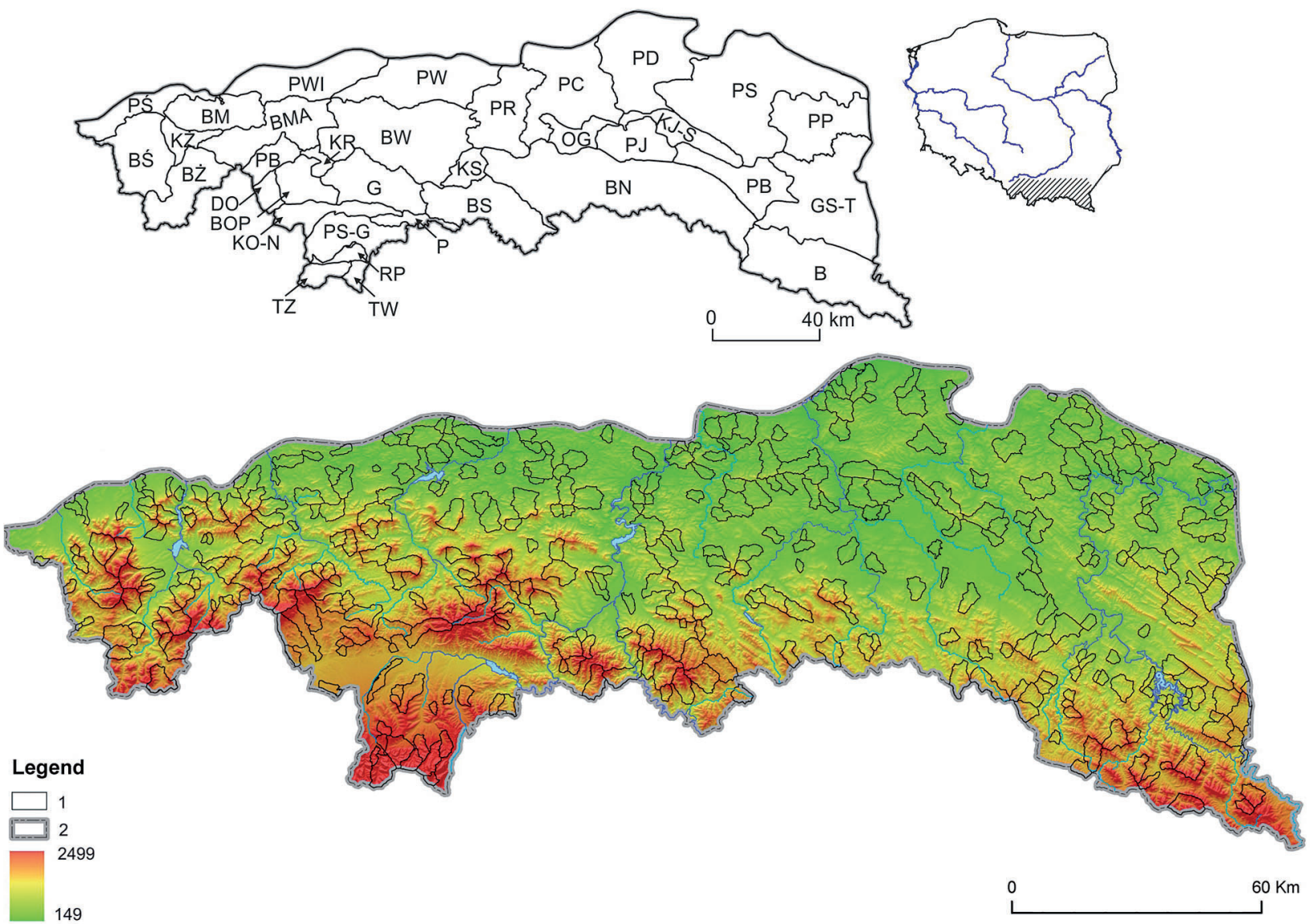

Fig. 6. Distribution of catchments where the "Horton's and Schumm's laws" were fulfilled. 1 - catchments, 2 - the study area Geographical regions after J. Kondracki (1994). PŚ - Śląskie Foothills, PWI - Wielickie Foothills, PW - Wiśnickie Foothills, PR - Rożnowskie Foothills, PC - Ciężkowickie Foothills, PD - Dynowskie Foothills, PS - Strzyżowskie Foothills, PP - Przemyskie Foothills, PB - Bukowskie Foothills, PJ - Jasielskie Foothills, PS-G - Spisko-Gubałowskie Foothills, BŚ - Beskid Śląski, BM - Beskid Mały, BŻ - Beskid Żywiecki, PB - the Babia Góra Ridge, DO - Działy Orawskie, BOP - Beskid Orawsko-Podhalański, BMA - Beskid Makowski, BW - Beskid Wyspowy, BS - Beskid Sądecki, BN - Beskid Niski, B - Bieszczady Mts. KS - Sądecka Basin, KR - Rabczańska Basin, KŻ - Żywiecka Basin, KO-N Orawsko-Nowotarska Basin, DJ-S - Jasielsko-Sanocka Basin, OG - Gorlice Basis, RT - Podtatrzański Trench, TW - the Eastern Tatra Mts., TZ - the Western Tatra Mts. P - the Pieniny Mts., GTS - the Sanocko-Turczańskie Mts. 

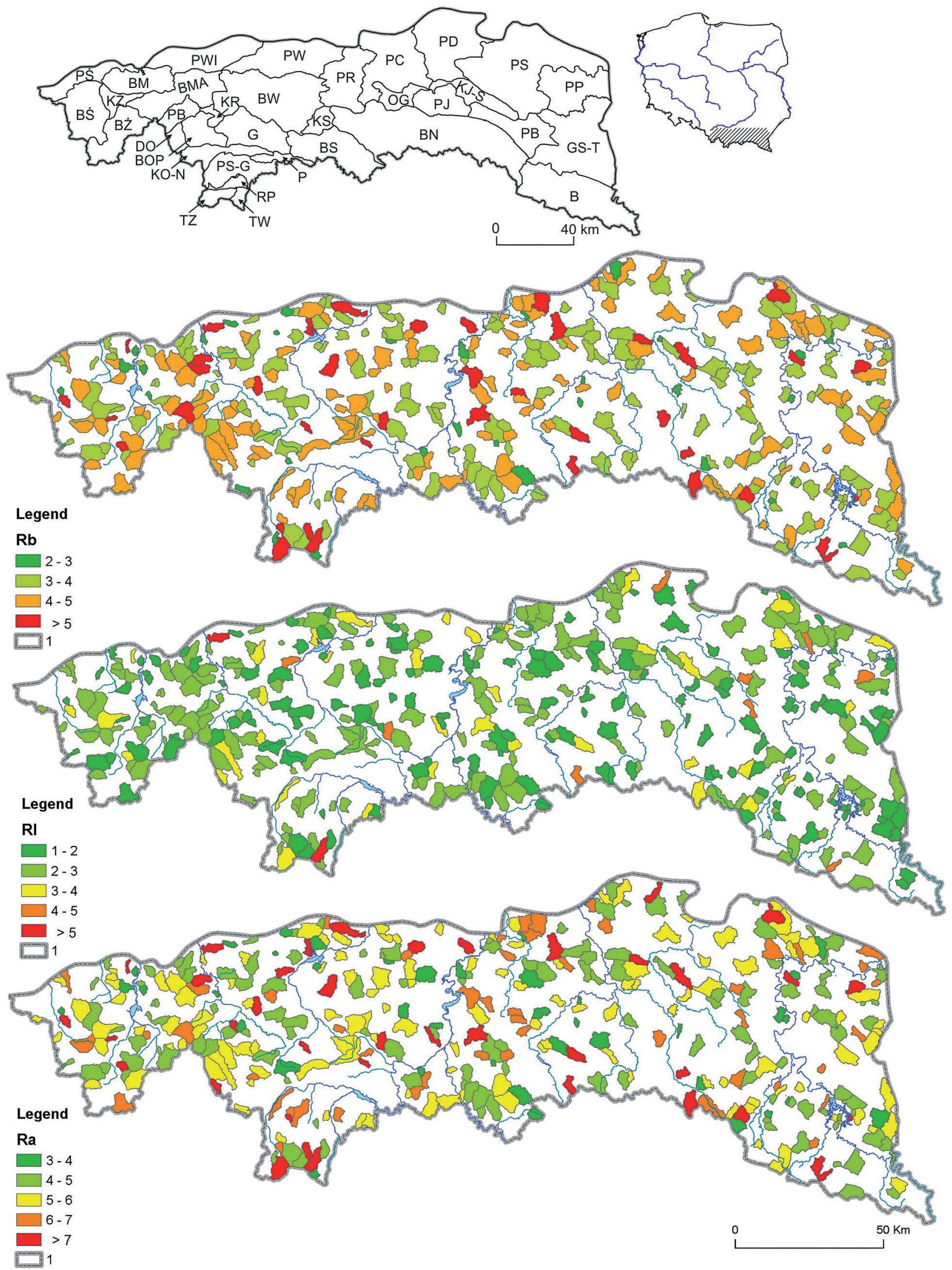

Fig. 7. The bifurcation ratio $\left(R_{B}\right)$, the length ratio $\left(R_{L}\right)$ and the area ratio $\left(R_{A}\right)$ in the catchments where the "Horton's and Schumm's laws" were fulfilled. 1 - the study area 
5-6; there was no regional diversity in the $\mathrm{R}_{\mathrm{A}}$ ratio's spatial distribution.

\section{Discussion}

Many studies (e.g. Shreve 1966, 1967, 1969, Smart 1968, Kirchner 1993) have discussed Horton's and Schumm's laws on the basis of "statistical models", and they have compared the results to natural river systems. In this way, Kirchner (1993) showed that, statistically speaking, roughly $95 \%$ of river systems obey Horton's and Schumm's laws, regardless of whether the systems are topologically random or not. In other words, almost all river systems should theoretically fulfill Horton's and Schumm's laws, regardless of the forcing factors that influence river system development (e.g. geology, relief, climate, etc.). A detailed investigation of natural river systems does not support this conclusion (Bajkiewicz-Grabowska 1987, Pristachova 1988). In the Polish Carpathians, the river systems of large catchments (a few hundred $\mathrm{km}^{2}$ in area) have not fulfilled the "law of stream length", in spite of the fact that the "law of stream number" was fulfilled (Bajkiewicz-Grabowska 1987). The same conclusion was reached by Bryndal (2012) within small catchments in the northeastern part of the Polish Carpathians. This study revealed that more than $50 \%$ of the small Carpathian catchments have not fulfilled the "law of stream length". If the river system had fulfilled Horton's and Schumm's laws, then the values of the $R_{B^{\prime}} R_{L^{\prime}}$ and $R_{A}$ ratios should be similar to those reported in other regions of the world (Morisawa 1962, Bras, Rodrigues-Iturbe 1989).

The general view is that geological settings and relief conditions may contribute to the failure to fulfill Horton's laws. However, this study revealed that there was no simple relationship between the regional diversity of geological settings, relief conditions, and the spatial distribution of catchment areas where Horton's and Schumm's laws were fulfilled. The catchments were observed on the foothills, in the mid-mountain terrain, and in the high-mountain regions of the Carpathians. Moreover, there were no significant regional differences in the values of the $R_{B^{\prime}}$ $R_{L^{\prime}}$ and $R_{A}$ ratios within the Carpathians. These results confirmed the limitation of Horton's and
Schumm's ratios in the evaluation of the influence of geological/geomorphological factors on river system development. As was emphasized by Kirchner (1993), Horton's ratios fail to identify river systems with distinctive characteristics, yielding only the singular imprecise conclusion that natural system networks are the subsets of all possible networks (Kircher 1993).

The fact that Horton's law is not fulfilled in many small catchment areas is important to consider from a practical point of view. It is worth remembering that catchments up to $35.2 \mathrm{~km}^{2}$ in area are usually affected by flash flooding in the Carpathians (Bryndal 2008, 2014a, b). As those catchments are rarely gauged, the hydrological data are usually obtained as a result of hydrological modeling. It is notable that the data obtained from these hydrological models are often the only source of information used in the design of hydrological infrastructure or in the mitigation of adverse impacts of flash flooding (e.g. by delineation of the inundated areas for p-probable flood events). Many studies have focused on the development or application of hydrological models where the $R_{B^{\prime}}, R_{L^{\prime}}$ and $R_{A}$ ratios are required as input data (e.g. Ziemońska, Żelaziński 1984, Więzik 1987, 2010, Soczyńska 1987, Nowicka, Soczyńska 1991, Ciupa 2010, Kroczak 2010). The results of this study thus suggest that the use of these models may be limited. Therefore, more attention should be placed on the hydrological models where the $R_{B^{\prime}}, R_{L^{\prime}}$ and $R_{A}$ ratios are not required.

\section{Conclusions}

The results of this study may be concluded as follow:

- The river systems of the small Carpathian catchments generally fulfill the "law of stream number" and the "law of stream areas". Detailed analyses of log-plots revealed that more than $50 \%$ of catchment areas do not fulfill the "law of stream length". This fact led to the conclusion that the applicability of many hydrological models where the $R_{B^{\prime}}, R_{L^{\prime}}$ and $R_{A}$ ratios were required as input data may be seriously limited. In this context, more attention should be given to the development and application of hydrological 
models where the $R_{B^{\prime}}, R_{L^{\prime}}$ and $R_{A}$ ratios are not required.

- When the river systems of the small Carpathian catchment fulfill Horton's and Schumm's laws, the values of the $\mathrm{R}_{\mathrm{B}^{\prime}}, \mathrm{R}_{\mathrm{L}^{\prime}}$, and $\mathrm{R}_{\mathrm{A}}$ ratios are similar to those reported in the other regions of the world.

- There is no simple relationship between the regional diversity of the geological settings, relief conditions, and spatial distribution of the catchment areas where the "law of stream number", the "law of stream length", and the "law of stream area" were or were not fulfilled. A similar conclusion was reached for the spatial distribution of the $R_{B^{\prime}} R_{L^{\prime}}$ and $R_{A}$ ratios. These results confirmed that the use of Horton's and Schumm's ratios in the evaluation of the influence of geological/geomorphological settings on river system development is limited.

\section{Acknowledgements}

English-language editing of this manuscript was provided by Journal Prep.

\section{References}

Ariza-Villaverde A.B., Jimenez-Hornero F.J., Gutierrez de Rave E., 2013. Multifractal analysis applied to the study of the accuracy of DEM based stream derivation. Geomorphology 197: 85-95.

Bajkiewicz-Grabowska E, 1987. Systemy rzeczne i stopień ich uporządkowania (The river systems and the degree of their order). Przeglad Geofizyczny 32(3): 303-318.

Bohner J., McCloy K.R., Strobl J., (eds.) 2006. SAGA Analysis and Modelling Applications. Gottinger Geographische Abhandlungen 115: 1-130.

Boni G., Ferraris L., Giannoni F., Roth G., Rudari R., 2007. Flood probability analysis for un gauged watersheds by means of a simple distributed hydrologic model. Advances in Water Resources 30: 2135-2144.

Bras R., L., Rodriguez-Iturbe I., 1989. A review of the search for quantitative link between hydrologic response and fluvial geomorphology. IAHS Publication 181: 149-163.

Bryndal T., 2008. Parametry zlewni w których wystąpiły lokalne powodzie (Parameters of basins where small-scale flooding occurred). ANNALES UMCS, sec. B, 63(10): 176-200.

Bryndal T., 2012. Sieć rzeczna małych zlewni pogórzy Strzyżowskiego Dynowskiego i Przemyskiego w świetle praw Hortona i Schumma - implikacje dla modelowania hydrologicznego przepływu (The river network in small basins of Strzyżowskie Dynowskie and Przemyskie Footfills in the context of the Horton's and Schumm's laws - implications for hydrological modelling of the discharge). Monografie Komisji Hydrologicznej PTG 1: 39-50.

Bryndal T., 2014a. Identyfikacja małych zlewni podatnych na formowanie gwałtownych wezbrań w Karpatach Pol- skich (Identification of small catchments prone to flash flood generation in the Polish Carpathians). Prace Monograficzne Uniwersytetu Pedagogicznego, 690: 3-180.

Bryndal, T. 2014b. A method for identification of small Carpathian catchments more prone to flash flood generation. Based on the example of south-eastern part of the Polish Carpathians. Carpathian Journal of Earth and Environmental Sciences 9(3): 109-122.

Ciupa T., 2010. Wptyw zagospodarowania terenu na odptyw $i$ transport fluwialny $w$ matych zlewniach na przykładzie Sufraganca i Sinicy (The impact of land use on runoff and fluvial transport in small river catchments - based on the Sufraganie and Silnica rivers). Wydawnictwo Uniwersytetu Humanistyczno-Przyrodniczego J. Kochanowskiego, Kielce.

Cox K.G., 1989. The role of mantle plumes in the development of continental drainage patterns. Nature 342: 873877.

Daniel J.R.K., 1981. Drainage density as a index of climatic geomorphology. Journal of Hydrology 50: 147-154.

Dobija A., Dynowska I., 1975. Znaczenie parametrów fizjograficznych dla ustalenia wielkości odpływu rzecznego (The importance of physiographic parameters for determining of the of the river outflow magnitude), Folia Geographica series Geographica Physica 9: 77-127.

Furey P.R., Troutman B.M., 2008. A consistent framework for Horton regression statistics that leads to a modified Hack's law. Geomorphology 102(3-4): 603-614.

Garcija-Ruitz J.M., Otalora F., 1992. Fractal trees and Horton's laws. Mathematical Geology 24(1): 61-71.

Gutry-Korycka M., 1987. Statystyczne metody opisu sieci rzecznej (Statistical methods of description of networks). Przegląd Geofizyczny 32(2): 147-163.

Hengl, T., Reuter, H.I. (eds), 2009. Geomorphometry: Concepts, Software, Applications. Elsevier, Amsterdam.

Horton R.E., 1945. Erosional development of streams and their drainage basins: hydrophysical approach to the quantitative morphology. Geological Society of America Bulletin 56: 275-370.

Jain S.K., Singh R.D., Seth S.M., 2000. Design Flood Estimation Using GIS Supported GIUH Approach. Water Resources Management 14: 369-376.

Jasiewicz J., Metz M., 2011. A new GRASS GIS toolkit for Hortonian analysis of drainage networks. Computers $\mathcal{E}$ Geosciences 37: 1162-1173. doi:10.1016/j.cageo.2011.03.003

Kondracki J., 1994. Geografia regionalna Polski (The regional geography of Poland), Wydawnictwo Naukowe PWN, Warszawa.

Kirby M.J., 1976. Test of the random network model, and its application to basin hydrology. Earth Surface Processes 1: 197-212.

Kirchner J.W., 1993. Statistical inevitability of Horton's laws and the apparent randomness of stream channel networks, Geology 21: 591-594.

Kroczak R., 2010. Geomorfologiczne i hydrologiczne skutki funkcjonowania dróg polnych na Pogórzu Ciężkowickim (Geomorphological and hydrological effects of unmetalled road network functioning on the example of Ciężkowickie Foothills), Prace Geograficzne IGiPZ PAN w Krakowie 225: 1-138.

La Barbera P., Roso R., 1992. On the fractal dimension of stream networks, Water Recourses Research 25: 735-741.

Lindsay, J.B., 2005. The terrain analysis system: A tool for hydro-geomorphic applications. Hydrological Processes 19: 1123-1130. 
Maidment D.R., 2002. ArcHydro GIS for Water Resources. Esri Press, Redlands.

Morisawa M.E., 1962. Quantitative geomorphology of some watersheds in the Appalachian Plateau. Geological society of America Bulletin 73: 1025-1046.

Nasi S., Cudennec C., Albergel J., Berndtsson R., 2004. Use of a geomorphological transfer function to model design floods in small hillside catchments in semiarid Tunisia. Journal of Hydrology 287: 197-213.

Nowicka B., Soczyńska U., 1991. Modelowanie odpływu powierzchniowego metodą geomorfologiczną i hydrodynamiczną (Modelling of the surface runoff by geomorphological and hydrological methods). Prace i Studia Geograficzne UW 12: 177-186.

Obrębska-Starklowa B., Hess M., Olecki Z., Trepińska J., Kowanetz L., 1995. Klimat (Climate), In: Warszyńska J. (ed.), Karpaty Polskie, Wydawnictwo Uniwersytetu Jagiellońskiego, Kraków: 31-47.

Ostrowski J., 1994. Model regionalny małej zlewni MOREMAZ-1 (The regional model of small catchments MOREMAZ-1). Materiaty badawcze IMGW, Hydrologia i Oceanologia 17: 1-128.

Oszczypko N., 1995. Budowa geologiczna (Geological settings), In: Waryszczyńska, J. (ed.), Karpaty Polskie. Wydawnictwo Uniwersytetu Jagiellońskiego, Kraków: 15-22.

Pristachova G., 1990. Quantitative geomorphology stream network and instantaneous unit Hydrograph. Hydrology in mountain areas. IAHS Publ no 190: 369-376.

Rosso R., Bacchi B., La Barbera P., 1991. Fractal relation of mainstream length to catchment area in river networks. Water resources Research 27(3): 381-387.

Ranalli G., Scheidegger A., 1968. Topological significance of stream labeling methods. Hydrological Sciences Journal 13(4): 77-85. doi:10.1080/02626666809493628

Rodriguez-Iturbe I., Valdes J.B., 1979. The geomorphologic structure of hydrologic response. Water Resources Research 15: 1409-1420.

Rosso R., 1984. Nash model relation to Horton order ratios. Water Recourses Research 20 (7): 914-920.

Scheidegger A.E., 1968. Horton's laws of stream lengths and drainage areas. Water Resources Research 4(5): 1015-1021.

Scheidegger A.E., 1970. Stochastic Models in Hydrology. Water Resources Research 6(3): 750-775. doi:10.1029/ WR006i003p00750
Schumm S.,A., 1956. Evolution of drainage systems and slopes in badlands and Perth Amboy, NY. Geological Society of America Bulletin 67: 597-646.

Shreve R.L., 1966. Statistical law of stream numbers. The Journal of Geology 74(1): 17-37.

Shreve R.L., 1967. Infinite topologically random channel networks. The Journal of Geology 75: 178-186.

Shreve R.L., 1969. Stream lengths and basin areas in topologically random channel networks. The Journal of Geology 77(4): 397-414.

Smart J.S., 1967. A comment on Hotron's laws and stream number, Water Resources Research 3: 773-776.

Smart J.S., 1968. Statistical properties of stream lengths. Water Resources Research 4: 1001-1014.

Smart J.S., 1972. Quantitative characterization of channel network structure. Water Resources Research 8(6): 1487-1496.

Soczyńska U., 1987. Geomorfologiczne podstawy symulacji hydrogramu w zlewni niekontrolowanej (Geomorphological foundations of Hydrograph simulation in ungauged catchments area). Przegląd Geofizyczny 32(2): 165-180.

Strahler A.,N., 1957. Quantitative analysis of watershed geomorphology. Transaction American Geophysical Union 63(6): 913-920.

Tarbon D.G 1996. Fractal river network, Horton's laws and Tokunaga cyclicity, Journal of Hydrology 187: 105-118.

Tarbaton D.G, Grass R.L., Rodriguez-Iturbe I., 1988. The fractal nature of river networks, Water Resources Research 24: 1,317-1,322.

Więzik B., 1987. Geomorfoklimatyczny hydrogram odpływu (Geomorfoclimatic runoff hydrograph). Przeglad Geofizyczny 32(3): 319-332.

Więzik B., 2010. Przepływy maksymalne roczne o określonym prawdopodobieństwie przewyższenia $\mathrm{w}$ małych zlewniach niekontrolowanych (Maximum annual flows of a given exceedance probability in small ungauged catchments). Monografie Komitetu Inżynierii Środowiska PAN 68: 153-165.

Ziemońska Z., Żelaziński J., 1984. Geomorfologiczny chwilowy hydrogram jednostkowy i jego wykorzystanie $\mathrm{w}$ modelu prognozy odpływu (Geomorphological Instantaneous Unit Hydrograph and its application in the runoff prediction model). Przeglad Geofizyczny 29(3): 317-331. 